\title{
Comment
}

\section{CIVIL LIABILITY OF SUBORDINATE STATE OFFICIALS UNDER THE FEDERAL CIVIL RIGHTS ACTS AND THE DOCTRINE OF OFFICIAL IMMUNITY}

The civil remedy sections of the Federal Civil Rights Acts $^{1}$ creating a claim for damages against "every person" who, under color of state law, deprives another of federally-secured rights, ${ }^{2}$ present difficult questions of policy where the defendant is a subordinate governmental official acting without discriminatory intent. The situation arises, for example, where an official, in line of official duty and in good faith, enforces a state statute which appears valid but is later declared unconstitutional. ${ }^{3}$ Some federal courts liave recently resolved the problem in favor of the subordinate official by resorting to the common law doctrine of official immunity. ${ }^{4}$ This Comment will attempt to appraise the developing use of immunity in damage actions arising under the Civil Rights Acts and will be directed to, first, the immunity doctrine at common law; second, the extent to which the doctrine has been imported into the Civil Rights Acts; and, third, an examination of policy and practical considerations affecting the desirability of the development.

\section{Common Law Doctrine of Official Immunity}

The doctrine of sovereign immunity ${ }^{5}$ requires that tort losses occasioned by much government activity be borne by either the injured citizen or the injurycausing official. ${ }^{6}$ For reasons of policy the common law often places the loss on the

1 The civil provisions of the Civil Rights Acts are found in REv. STAT. $\$ \S 772,1977-85$, 1987-90, 5517, 18 STAT. 337 (1875), as amended, 42 U.S.C. $\$ \S 1891-93$ (1952). These statutes originated in the following enactments in the decade following the end of the Civil War: Act of April 9, 1866, 14 Stat. 27; Act of May 31, 1870, 16 Stat. 140; Act of Feb. 28, 1871, 16 Stat. 433; Act of April 20, 1871, 17 STAт. 13; and Act of March 1, 1875, 18 Stat. 335.

2 REV. STAT. \& 1979 (1875), 42 U.S.C. \$ 1983 (1952).

${ }^{3}$ See, e.g., Smith v. Allwright, 321 U.S. 649 (1944); Lane v. Wilson, 307 U.S. 268 (1939); Nixon v. Condon, 286 U.S. 73 (1932); Nixon v. Herndon, 273 U.S. 536 (1927); Myers v. Anderson, 238 U.S. 368 (1915) ; cf. Dunn v. Gazzola, 216 F.2d 709 (1st Cir. 1954).

4 See Francis v. Lyman, 216 F.2d 583 (1st Cir. 1954) (superintendents of mental institution who held plaintiff under confinement pursuant to judicial decree, fair on its face, but issued under statute not providing for due process); Dunn v. Gazzola, 216 F.2d 709 (1st Cir. 1954) (superintendent of reformatory who confined plaintiff pursuant to judicial decree, fair on its face, issued without due process); Kenny v. Hatfield, 132 F. Supp. 814 (W.D.Mich. 1955) (superintendent and physician of state hospital who confined plaintiff under decree, fair on its face, which was in fact invalid).

5 See, generally, Borchard, Government Liability in Tort, 34 Y YIL L.J. 1, 129, 229 (192425), Government Responsibility in Tort, 36 YArE L.J. 1, 757, 1039 (1926-27), 28 CoLUM. L. REv. 577 (1928), Theories of Governmental Responsibility, 28 CoLUM. L. REv. 734 (1928). See also Prosser, TorTs 770-80 (1955). "The origin of this idea seems to have been the common law notion that 'the King can do no wrong'.... When the individual sovereign was replaced by the broader conception of the modern state, the idea was carried over that to allow a suit against a ruling government without its consent was inconsistent with the very idea of supreme executive power." Id. at 770-71.

6 The statement is valid in so far as the government does not consent to be sued. See, generally, Fietd, The EFFECT of aN UNconstitutional Statute 145-49 (1935). Many governments have, by statute, provided for various degrees and forms of consent to suit. One method is to permit suits by private citizens directly against the state for enumerated torts. See, e.g., Federal Tort Claims Act, 28 U.S.C. $\$ \$ 1346,1402,1504$, 2110, 2401-02, 2411-12, 2671-80 (1952), permitting suits against the United States for a limited variety of torts. Another method of amelio- 
citizen by granting immunity to the official. Normally, judges of courts of general jurisdiction, ${ }^{7}$ legislators, ${ }^{8}$ and the highest executives ${ }^{8}$ of the national and state governments are granted absolute immunity. So long as the tortious act arises in the course of official activity, the action is privileged, even if motivated by malice or corruption. ${ }^{10}$ The reasons commonly advanced in support of this official immunity are the need to preserve the independence of governmental officials who can make decisions uminfluenced by fear of personal hability, ${ }^{11}$ the fear that defending constant and vexing suits will impair the official's efficiency, ${ }^{12}$ and the unfairness of requiring the official to exercise judgment and, simultaneously, holding him hable for errors of judgment. ${ }^{13}$

The common law regarding the immunity of subordinate officials, however, is not clearly settled. Some courts distinguish between "discretionary" or "quasijudicial"14 acts, requiring deliberation and exercise of judgment, and "ministerial" acts, necessitating only the performance of a predetermined duty. ${ }^{15}$ If the tortious act is discretionary, immunity is accorded the official ${ }^{16}$ if merely ministerial, the privilege is not available. ${ }^{17}$ Practically, however, difficulty arises in drawing the hine between the two for the "distmction, if it exists, can be at most one of degree ...."18 Further, even where the privilege of immunity is available, there is

rating the harsh consequences of the sovereign immunity doctrine is to require suits against the official, rather than against the government itself, but to reimburse the official for hitigation expenses and, possibly, for dannages awarded. See, e.g., Car. Govr. Cone §§ 2001-02 providing for government counsel and reimbursement of litigation expenses in defending negligence actions where the official acted in good faith without malice. See also Cax. Govr. CODE $\$ 1956$ authorizing the state and local governments to provide, at government expense, liability insurance for the protection of officials against tort liability for negligence. Sce, generally, Note, 68 HaRv. L. REv. 506 (1955), discussing various state acts waiving sovereign immunity from suit.

7 Alzua v. Johnson, 231 U.S. 106 (1913) ; Bradley v. Fisher, 80 U.S. (7 Wall.) 335 (1871).

8 Tenney v. Brandhove, 341 U.S. 367 (1951) ; Kilbourn v. Thompson, 103 U.S. 168 (1880).

9 Moyer v. Peabody, 212 U.S. 78 (1909); Spalding v. Vilas, 161 U.S. 483 (1896).

${ }^{10}$ See, e.g., Bradley v. Fisher, 80 U.S. (7 Wall.) $335,347-48$ (1871).

11 Id. at 347 .

12 Spalding v. Vilas, 161 U.S. 483, 498-99 (1896).

13 See Prosser, TorTs 780 (1955) ; Keefe, Personal Tort Liability of Administrative Officials, 12 Fordmax L. REv. 130, 131 (1943); Jennings, Tort Liability of Administrative Officers, 21 MINN. L. REv. 263, 271 (1937).

14 Many courts appear to use the term "quasi-judicial" in a broad sense. When used in the immunity context the term refers not only to adjudicative functions performed by administrative bodies but also to duties performed by nonjudicial officials who participate in judicial proceedings, such as prosecuting attorneys and jurors, and to many other functions demanding the exercise of judgment and discretion. See, e.g., Cawley v. Warren, 216 F.2d 74 (7th Cir. 1954) (prosecuting attorney and grand jurors immune from liability as quasi-judicial officials).

16 See Prosser, TORTs 781-82 (1955).

16 Some courts have classified as "discretionary" the acts of "a prosecuting attorney in connection with an indictunent, an assessor valung property for taxes, a school board dismissing a pupil, or a superintendent refusing a license to a teacher, as well as the letting of a contract to the lowest responsible bidder, the routing of a highway, or the approval of a surety bond ...." Id. at 781. (Footnotes omitted.)

17 Some courts have classified as "ministerial" the "preparation of ballots, the registration of voters, the recording of documents, the filing of papers, the care of prisoners, the driving of vehicles, the repair of highways, the collection of taxes, the signing of licenses, the taking of acknowledgments, and dipping sheep." Id. at 782. (Footnotes omitted.)

$18 \mathrm{Ibid}$. The discretionary-ministerial distinction has been criticized by Professor E. G. Jennings who advocated its abandonment and the substitution of a good faith-reasonable care test. Jennings, Tort Liability of Administrative Officers, 21 MINN. L. REv. 263, 301 (1927). Sound reasons support Jennings' view. The social advantages in insulating public officials froin 
considerable uncertainty as to the degree or scope of protection afforded. Most cases state that the privilege, unlike that accorded judges and legislators, is qualified, that is, the subordinate is protected only if he acts in the good faith belief that his actions are not tortious. ${ }^{19}$ Nonetheless some courts ${ }^{20}$ hold the privilege to be absolute. ${ }^{21}$

\section{Recent Extension of Immunity Doctrine to Civil Rights Acts Cases}

The primary provisions of the Civil Rights Acts imposing civil sanctions are worded to apply to "every person" without expressly excepting any group. Thus section $1983^{22}$ provides for legal or equitable relief against "every person" who, under color of state law, deprives another of any "rights, privileges, or immunities" secured by the Constitution or federal laws. ${ }^{23}$ Section $1985(3)^{24}$ provides for an action at law against any "two or more persons" who conspire to deprive another of the "equal protection" or "equal privileges or immunities" under the law. ${ }^{25}$ The Supreme Court, in a series of Civil Rights Acts decisions invalidating state election and registration statutes found to discriminate on the basis of race or color, imposed personal hability on subordinate officials without any discussion of immunity. ${ }^{26}$ Nonetheless, there remained considerable speculation whether the

personal liability for honest errors of judgment applies to subordinate officials as well as to judges, legislators and superior executive officers. Moreover, once the absolute immunity of the latter group is conceded, the injustice of imposing liability on the well-intending subordinate acting in conformity with their orders is manifest. Such reasons, however, do not warrant the conferring of absolute immunity for the reasons lose persuasiveness when applied to malicious misbehavior. While some measure of immunity may be necessary for the orderly efficient functioning of government, it is difficult to see how the public interest is served by protecting malicious or corrupt conduct of lesser officials.

10 See, e.g, Spenger v. School Dist. No. 1, 82 Colo. 534, 261 Pac. 859 (1927) ; Hedgepeth v. Swanson, 233 N.C. 442, 27 S.E.2d 122 (1943); cf. Dinsman v. Wilkes, 53 U.S. (12 How.) 389 (1851).

20 See, e.g., Papagianakis v. The Samos, 186 F.2d 257 (4th Cir. 1950) ; Phelps v. Dawson, 97 F.2d 339 (8th Cir. 1938) ; Nadeau v. Marchessault, 112 Vt. 309, 24 A.2d 352 (1942).

21 Some courts draw another distinction between action and nonaction. Tortious conduct by a subordinate official consisting of affirmative action is actionable; mere nonaction is privileged. See, e.g., Smith v. Iowa City, 213 Iowa 391, 239 N.W. 29 (1931) ; Stevens v. North State Motor, 161 Minn. 345, 201 N.W. 435 (1925).

22 Rev. STAT. $\$ 1979$ (1875), 42 U.S.C. $\$ 1983$ (1952), formerly 8 U.S.C. $\$ 43$ (1946).

23 "Every person who, under color of any statute, ordinance, regulation, custom, or usage, of any State or Territory, subjects, or causes to be subjected, any citizen of the Umited States or other person within the jurisdiction thereof to the deprivation of any rights, privileges or immunities secured by the Constitution and laws, shall be liable to the party injured in an action at law, suit in equity, or other proper proceeding for redress." REv. STat. \$ 1979 (1875), 42 U.S.C. $\$ 1983$ (1952). (1946).

24 Rev. STAT. § $1980(3)$ (1875), 42 U.S.C. § $1985(3)$ (1952), formerly 8 U.S.C. § 47 (3)

25 "If two or more persons in any State or Territory conspire or go in disguise on the highway or on the premises of another, for the purpose of depriving, either directly or indirectly, any person or class of persons of the equal protection of the laws, or of equal privileges and immunities under the laws; ... in any case of conspiracy set forth in this section, if one or more persons engaged therein do, or cause to be done, any act in furtherance of the object of such conspiracy, whereby another is injured in his person or property, or deprived of having and exercising any right or privilege of a citizen of the United States, the party so injured or deprived may lrave an action for the recovery of damages, occasioned by such imjury or deprivation, against any one or more of the conspiracy." REv. STAT. § 1980(3) (1875), 42 U.S.C. $\S 1985$ (3) (1952).

26 Smith v. Allwright, 321 U.S. 649 (1944) (prohibition of Negro participation in primary election) ; Lane v. Wilson, 307 U.S. 268 (1939) (registration statute discriminating against Negroes by variation on "grandfather clause") ; Nixon v. Condon, 286 U.S. 73 (1932) ("white primary"); Nixon v. Herndon, 273 U.S. 536 (1927) ("white primary"); Myers v. Anderson, 238 U.S. 368 (1915) (state constitution with "grandfather clause"). 
broad language of the Civil Rights Acts was intended to supersede the common law doctrine of judicial, legislative, and executive immunity. ${ }^{27}$ The 1951 Supreme Court decision in Tenney v. Brandhove ${ }^{28}$ settled the legislative immunity question. This was an action for damages commenced under sections 1983 and $1985(3)^{20}$ against certain state legislators who had allegedly utilized legislative investigating committee procedures in an unsuccessful atteinpt to secure a contempt conviction in violation of the plaintiff's constitutional rights. ${ }^{30}$ Justice Frankfurter, writing for the majority, recounted the long history and the policy considerations behind legislative immunity and held that legislators were excepted from the operation of the Civil Rights Acts. He found the concept of legislative immunity too deeply entrenched in tradition to imfer congressional intent to supersede it merely from the broad wording of the acts. ${ }^{31}$ That the immunity is absolute was revealed by Justice Frankfurter's statement that "the claim of an unworthy purpose does not destroy the privilege."32 And while the case did not involve racial discrimination, there is nothing in the opinion to suggest that a different result would obtain if discrimination were based on race. ${ }^{33}$

The circuit and district courts lost little time in applying the immunity doctrine to judges. Although Tenney remains the only Supreme Court pronouncement on immunity in Civil Rights Acts cases, the absolute immunity of the judiciary now appears well established..$^{34}$ Sonıe courts have extended the concept of judicial immunity to cover nonjudicial officials who participate in judicial proceedings. ${ }^{35}$

27 Compare United States v. Chaplin, 54 F. Supp. 926 (S.D. Cal. 1944) (Civil Rights Act did not supersede judicial imnunity), with Picking v. Pennsylvania R.R., 151 F.2d 240 (3d Cir.), cert. denied, 332 U.S. 776 (1945) (Civil Rights Acts supersede judicial immunity).

28341 U.S. 367 (1951).

29 At the time of suit 42 U.S.C. $\$ 1983$ (1952) was 8 U.S.C. $\$ 43$ (1946), and 42 U.S.C. $\$ 1980$ (3) (1952) was 8 U.S.C. $\$ 47(3)$ (1946). The language of these statutes is identical. For purposes of convenience, these sections will be referred to in the text by their current designations.

30 The plaintiff alleged he was deprived of free speech, of the right to petition the state legislature for redress of his grievances, of the equal protction of the laws, of due process, and of equal privileges and immunities. Tenney v. Brandhove, 341 U.S. 367, 371 (1951).

31 "We cannot helieve that Congress-itself a staunch advocate of legislative freedomwould impinge on a tradition so well grounded in history and reason by covert inclusion in the general language before us." Id. at 376 .

32 Id. at 377.

33 See Note, 68 HaRv. L. REv. 1229, 1234 (1955), for a view critical of Tenney v. Brandhove for seemingly applying legislative immunity in Civil Rights Acts actions without distinguishing racial from nonracial discrimination.

34 See, e.g., Tate v. Amold, 223 F.2d 782 (8th Cir. 1955) ; Francis v. Crafts, 203 F.2d 809 (1st Cir.), cert. denied, 346 U.S. 835 (1953); Grubbs v. Slater, 133 F. Supp. 110 (W.D. Ky. 1955); Oppenheimer v. Stillwell, 132 F. Supp. 761 (S.D. Cal. 1955); Kenney v. Fox, 132 F. Supp. 305 (W.D. Mich. 1955).

The tradition of judicial immunity is so strongly entrenched that some courts adopted it prior to the Tenney decision. See, e.g., Souther v. Reid, 101 F. Supp. 806 (E.D.Va. 1951); United States v. Chaplin, 54 F. Supp. 806 (S.D. Cal. 1944).

Prior to the Tenney case, there were only two decisions expressly denying judicial immunity. These are McShane v. Moldovan, 172 F.2d 1016 (6th Cir. 1949), and Picking v. Pennsylvania R.R., 151 F.2d 240 (3d Cir.), cert. denied, 332 U.S. 776 (1945). But see Ginsberg v. Stern, 225 F.2d 245 (3d Cir. 1955), where the United States Court of Appeals for the Third Circuit, affirming dismissal of a Civil Rights Acts damage claim against a judge, expressly refrained from deciding whether Picking had been overruled hy Tenney $v$. Brandhove.

35 See, e.g., Jennings v. Nester, 217 F.2d 153 (7th Cir.), cert. dented, 349 U.S. 958 (1954) (state attorney prosecuting suit immune); Cawley v. Warren, 216 F.2d 74 (7th Cir. 1954) (prosecuting attorney and grand jurors immune); Ginsherg v. Stern, 125 F. Supp. 596 (W.D. Pa. 1954), aff'd mem., 225 F.2d 245 (3d Cir. 1955) (court clerk iminune) ; Morgan v. Sylvester, 
As with judges, the immunity accorded to these officials appears absolute. ${ }^{36}$ And like the Tenney opinion the cases granting judicial immunity contain no language indicating that the privilege is restricted to discrimination of a nonracial character. ${ }^{37}$

The immunity of judges, legislators, and high executive officers from Civil Rights Acts civil hability appearing to be fairly well settled, a real and present problem concerns subordinate officials not directly participating in legislative or judicial processes. ${ }^{38} \mathrm{~A}$ few recent Civil Rights Acts decisions have extended a hmited good-faith privilege of immunity to lesser subordinate officials. ${ }^{39}$ The leading case is Francis v. Lyman, ${ }^{40}$ decided in the First Circuit. The plaintiff was confined im a state mental institution pursuant to a judicial decree issued under a state statute failing to provide proper procedural safeguards. After securing her release by habeas corpus because a fair hearing had been denied, plaintiff cominenced a statutory damage action under the Civil Rights Acts against numerous officials responsible for her confinement. ${ }^{41} \mathrm{~A}$ dismissal of the action against the superintendents directly in charge of the institutions was based squarely on goodfaith immunity. ${ }^{42}$ In support of the holding Judge Magruder emphasized the "preposterous result" of granting immumity to state legislators who enacted the statute, wlile holding liable the subordinates who in lime of duty executed a seemingly valid judicial decree issued under that statute. ${ }^{43}$

\section{Desirability of Granting Immunity to Subordinate Officials: Policy Considerations in Nonracial Cases}

The general policy factors favoring immunity of officials from personal liability apply, to a large extent, to civil rights actions. In cases not involving racial discrimmation it would seem that the official should be equally immunized against state and federal tort suits. In addition is the policy against undue federal imterference in the day to day conduct of state and local government "to avoid the appalling inflammation of delicate state-federal relationships which undoubtedly would ensue"44 if every alleged impingement upon federal rights, however shight,

125 F. Supp. 380 (S.D.N.Y. 1954) (prosecuting attorney immune); Dunn v. Estes, 117 F. Supp. 146 (D. Mass. 1953) (probation officer making recommendation to judge immune); cf. Lyons v. Baker, 180 F.2d 893 (5th Cir.), cert. denied, 340 U.S. 828 (1950) (grand jurors).

36 See, e.g., Jennings v. Nester, 217 F.2d 153 (7th Cir.), cert. denied, 349 U.S. 958 (1954); Cawley v. Warren, 216 F.2d 74 (7th Cir. 1954); Dunn v. Gazzola, 216 F.2d 709 (1st Cir. 1954).

37 See cases cited in notes 34 and 35 supra. It is not clear from the opinions in the cited cases whether racial discrimination was involved. None of the decisions, however, made any distinction between racial and nonracial discrimination; hence, it would appear that judicial immunity would be available even in racial discrimination cases.

38 This discussion will be limited to the civil hability of nonjudicial, nonlegislative subordinate officials for Civil Rights Acts violations. In the interests of convenience, this category of lesser officials will be referred to simply as "subordinate officials."

39 See cases cited in note 4 supra.

40216 F.2d 583 (1st Cir. 1954).

41 The action against the judge was dismissed on grounds of judicial immunity. Francis v. Crafts, 203 F.2d 809 (1st Cir.), cert. denied, 346 U.S. 835 (1953). The action as against nembers of a parole board, failing to grant applications for parole, was dismissed on grounds that plaintiff failed to allege "purposeful discrimination." Francis v. Lyman, 216 F.2d 583 (1st. Cir. 1954). The action against the commissioners of correction was dismissed on the grounds that the commissioners had no personal duty to act. Id. at 585 .

42 Id, at 588 .

43 Ibid.

44 Ibid. 
gave rise to a right to damages against the subordinate official in a federal court.

As a matter of fact, pre-Tenney case law tended to reach the same results as the good-faith immunity doctrme by more indirect means. Many dainage clains agamst officials acting in good faith were seemingly dismissed by the imposition of technical pleading ${ }^{45}$ or procedural ${ }^{46}$ requirements, by failing to find unconstitutional behavior, ${ }^{47}$ or by strictly construing the scope of the Civil Rights Acts. ${ }^{48}$ Yet where official conduct was malicious the requirements were sometimes relaxed ${ }^{49}$ and recoveries usually permitted..$^{50}$

Another technique used to reheve well-meaning officials from personal hability was the "purposeful discrimination" test introduced by dictum in Snowden $v$. Hughes. ${ }^{51}$ This test, available where an individual alleges treatment less favorable than that accorded others, requires that "intentional or purposeful discrimination" be alleged in order to state a cause of action for denial of equal protection. ${ }^{62}$ The dictum was followed by some lower courts to provide relief where purposeful discrimination was apparently satisfactorily shown ${ }^{63}$ and to deny relief where official conduct appeared motivated by good intentions. ${ }^{54}$

45 See, e.g., Dinneen v. Williams, 219 F.2d 428 (9th Cir. 1955) (failure to properly allege "color of law"); United Elec. Radio Workers v. General Elec. Co., 127 F. Supp. 934 (D.D.C. 1954) (failure to support mere conclusions of law).

46 See, e.g., Mitchell v. Greenougl, 100 F.2d 184 (9th Cir. 1938) (statute of limitations not tolled while plaintiff incarcerated).

47 See, e.g., Moyer v. Peabody, 212 U.S. 78 (1908) (detention by governor during insurrection); Ortega v. Ragen, 216 F.2d 561 (7th Cir.), cert. denied, 339 U.S. 940 (1954) (interference by warden with prisoner mail); Wall v. King, 206 F.2d 878 (1st Cir.), cert. denied, 346 U.S. 915 (1953) (revocation of automobile driver's license); Siegcl v. Ragen, 180 F.2d 785 (7th Cir.), cert. denied, 339 U.S. 990 (1950) (refusing prisoner permission to practice law in prison); Watchtower Bible \& Tract Soc'y v. Los Angeles County, 181 F.2d 739 (9th Cir.), cert. denied, 340 U.S. 820 (1950) (ad valorem tax on personal property of religious organization); Saunder v. Wilkins, 152 F.2d 235 (4th Cir. 1945) (suit to enforce reapportionment of congressional district).

48 See, e.g., Holt v. Indiana Mfg. Co., 176 U.S. 68 (1900) (protection against impairment of contract not a "civil right") ; Bowman v. Chicago N.W. R.R., 115 U.S. 611 (1885) ; Jennings v. Nester, 217 F.2d 153 (7th Cir.), cert. denied, 349 U.S. 958 (1954) (suit agaimst policemen for unlawful search and seizure dismissed as plaintiff convicted on fair retrial); Brawner v. Irvin, 169 Fed. 964 (C.C.N.D. Ga. 1909) (bodily assault is deprivation of privilege and immunity of state citizenship and not within Civil Rights Acts) ; Marcus Brown Holding Co. v. Pollak, 272 Fed. 137 (S.D.N.Y.1920) (state statute restricting landlord's reentry upon land after default by tenant not violation of "civil rights.")

49 See, e.g., Geach v. Moynihan, 207 F.2d 714 (7th Cir. 1953) (color of law may be inferred from alleged facts).

50 See, e.g., Lewis v. Brautigam, 227 F.2d 124 (5th Cir. 1955) (police violence); Geach v. Moynihan, 207 F.2d 714 (7th Cir. 1953) (illegal search, seizure, and arrest) ; Davis v. Turner, 197 F.2d 847 (5th Cir. 1952) (illegal searcl and arrest, police brutality) ; McCollum v. Mayfield, 130 F. Supp. 112 (N.D.Cal. 1955) (refusing inedical care to prisoner awaiting trial); Dye v. Cox, 125 F. Supp. 714 (E.D. Va. 1954) (unlawful arrest, police brutality). In these cases the theoretical difficulty of finding state action does not appear to have unduly bothered the courts. Cf. Screws v. United States, 325 U.S. 91, 107-12 (1945).

ธ1 321 U.S. 1 (1943). In this case a primary election candidate for state office alleged that members of a canvassing board failed to certify his nomination although other successful nominees were duly certified. The Supreme Court affirmed dismissal by the trial court on grounds the complaint failed to state a cause of action. However, the Supreme Court stated that action for denial of equal protection of the laws miglit lie if the plaintiff liad established "intentional or purposeful discrimination." Id. at 8.

52 Ibid.

53 Glicker v. Michigan Liquor Control Comm'n, 160 F.2d 96 (6th Cir. 1947) (discriminatory revocation of liquor license, action for mandatory injunction) ; Burt v. City of New York, 156 F.2d 791 (2d Cir. 1946) (repeated denial of architect's certificate).

54 McQuire v. Todd, 198 F.2d 60 (5th Cir.), cert. deried, 344 U.S. 835 (1952) (alleged discriminatory prosecution and conviction in state court for refnsing to permit fire inspection 
The net result of the two approaches-technical requirements and purposeful discrimination-was that Civil Rights Acts claims against subordinate officials acting in good faith were rarely successful. Thus it is submitted that the importation of the good-faith immunity doctrine into nonracial Civil Rights Acts actions is desirable. The doctrine should not reduce the number of recoveries. Indeed, it may in the long run increase them by reducing the need for imposing rigid technical requirements, for straining to avoid finding unconstitutional behavior, and for narrowly construing the scope of the Civil Rights Acts. ${ }^{55}$

\section{Policy Considerations in Racial Discrimination Cases}

In racial discrimination cases, however, there are additional factors to be considered. The historical purpose of the Civil Rights Acts was to protect Negroes against discrimination. Such discrimination most often occurs in a chinate of community prejudice and bias where state legal protection may be ineffectual or wholly lacking. The enactment of the acts reflects the assertion of superior national power in the civil rights sphere, and any judicial rule impairing the effective exercise of that asserted power is not desirable. The force of the acts in lessening discrimination must fall upon state officials personally because the fourteenth amendment, furnishing the constitutional basis for the acts, does not permit federal intervention in private discrimination ${ }^{56}$ and because the sovereign inmunity concept does not permit suits by individuals against nonconsenting states. ${ }^{57}$ The immunization of subordinate officials, therefore, poses the danger of defeating the historical purpose of the acts and any movement in that direction requires careful consideration.

Furthermore, the nature of racial discrimination presents problems not ordinarily arising in tort actions. Since the particular acts of discrimination are often a manifestation of a general community-wide prejudice against an entire race, rehef in state courts is not available in any realistic sense. Securing access to federal courts, therefore, is extremely important. When racial discrimination occurs in judicial or quasi-judicial administrative proceedings, a federal hearing or review is normally obtainable; ${ }^{58}$ for examples, habeas corpus lies in event of unlawful incarceration ${ }^{59}$ and certiorari to the Supreme Court may be available in event of an unfair trial..$^{60} \mathrm{But}$ when the discrimmatory acts take place outside of judicial

of premises). See also the following cases using the Snowden $v$. Hughes test as alternate grounds for dismissal: Ortega v. Ragen, 216 F.2d 561 (7th Cir. 1954); Campo v. Niemeyer, 182 F.2d 115 (7th Cir. 1950); Mitchell v. Greenough, 100 F.2d 184 (9th Cir.), cert. denied, 306 U.S. 659 (1938); Morgan v. Sylvester, 125 F. Supp. 380 (S.D.N.Y. 1954). Acts.

55 See Note, 66 Harv. L. Rev. 1285 (1953), for a discussion of the scope of the Civil Rights

56 Civil Rights Cases, 109 U.S. 3 (1883); see also Comment, The Impact of Shelley v. Kraemer on the State Action Concept, 44 CaLIF. L. REv. 718 (1956), for a discussion of recent developments respecting the "state action" requirement read into the fourteenth amendment by the Supreme Court in the Civil Rights Cases, supra.

57 See authorities cited in notes 5 and 6 supra.

58 Cf. 18 U.S.C. $\$ 1257$ (3) (1952) (providing for review by the Supreme Court of final judgments or decrees of the highest state court in which a decision can be had by writ of certiorari where inter alia "any title, rights, privilege or immunity ..." is specially set up or claimed under the Constitution or laws of the United States); 18 U.S.C. $\$ 2241$ (c)(3) (1952) (granting power to the Supreme Court, any justice thereof, the district courts and any circuit judge to grant writs of habeas corpus to prisoners in custody of state authorities in violation of the Constitution or laws of the United States).

59 Darcy v. Handy, 351 U.S. 454 (1956) ; Hawk v. Olson, 326 U.S. 271 (1945). (1945).

Go Stroble v. California, 343 U.S. 181 (1952); Malinowski v. New York, 324 U.S. 401 
proceedings, as when the right to vote or to attend public school is unconstitutionally invaded, it would be difficult to raise the constitutional issue ${ }^{01}$ in the absence of the Civil Rights Acts and accompanying jurisdictional statutes. ${ }^{62}$ Moreover, standing and ripeness problems are acute as mere delay in securing adequate legal protection in the latter instances can result in virtual disfranchisement or loss of a semester of schooling.

It is to be noted that Judge Magruder in Francis v. Lyman ${ }^{83}$ distinguished racial discrimination, granting immunity to subordinates only in nonracial cases, stating: 64

\begin{abstract}
Where the [Civil Rights] act has been invoked in situations which no doubt were a major concern of the Reconstruction Congress-for instance, where members of a state board for the registration of voters have refused to permit the registration of a Negro, acting under color of discriminatory state legislation-the Supreme Court has not been loath to impose tort liability ... under the Civil Rights Acts. ... But beyond such situations, it seems to be the tendency of the decisions to restrict the applications of the Civil Rights Act, so as to avoid the appalling inflammation of delicate state-federal relationships which undoubtedly would ensue. ${ }^{65}$
\end{abstract}

Francis $v$. Lyman thus poses the question whether immunity must be denied subordinate officials in racial discrimination cases, first, as a matter of precedent, and, second, as a matter of policy.

\title{
Precedent Value of Pre-Tenney Racial Discrimination Decisions
}

There are a number of Supreme Court decisions which appear to deny immunity to subordmate officials who execute racially discriminatory enactments. The cases are Myers v. Anderson ${ }^{66}$ and Lane $v$. Wilson, ${ }^{67}$ invalidating the "grandfather clause," and Nixon v. Herndon, ${ }^{68}$ Nixon v. Condon, ${ }^{60}$ and Smith v. Allwright, ${ }^{70}$ decreeing the "white primary". unconstitutional. In each case the constitutional issue was raised by commencing a Civil Rights Acts damage action against the election or registration officials executing the statutes, and in each instance the Supreme Court, finding the statutes unconstitutional, held the defendants personally liable without discussion of immunity.

In spite of the seeming conclusiveness of the foregoing cases, there are reasons to believe that the question of immunity in racial discrimination cases was not thereby foreclosed. All of the cases were decided prior to Tenney v. Brandhove. ${ }^{71}$

01 While this argument applies primarily to racial cases, it may nonetheless apply to some nonracial matters, e.g., where local standards in the administration of criminal justice are so lax as to justify federal interference.

6228 U.S.C. $\$ 1343$ (1952) (grants original jurisdiction to the district courts in Civil Rights Acts claims without imposing requirements of diversity of citizenship or any amount in controversy).

63216 F.2d 583 (1st Cir. 1954).

$64 I d$. at 588 .

65 The writer of Note, 68 HaRv. L. REv. 1229 (1955), agrees that unmunity should be available only in nonracial cases. The writer draws the distinction along the lines of due processequal protection, contending that the privilege should be available where due process is invaded, but not where equal protection is denied.

68238 U.S. 368 (1915).

67307 U.S. 268 (1939).

68273 U.S. 536 (1927).

60286 U.S. 73 (1932).

70321 U.S. 649 (1944).

71341 U.S. 367 (1951). 
Moreover, it seems that the defendants did not forcefully or directly argue immunity. In only one case, Myers $v$. Anderson, does the immunity question appear to have been raised; ${ }^{72}$ further, the issue seems to have been argued only by implication, ${ }^{73}$ and the court opinion does not even bother to answer it. ${ }^{74}$ In Smith $v$. Allwright and Nixon v. Herndon it appears the defendants failed to appear or to file briefs; ${ }^{75}$ briefs of amici curiae, addressed solely to the constitutionality of the statutes, entirely omitted discussion of immunity. ${ }^{76}$ In the remaining two cases, Lane v. Wilson and Nixon v. Condon, briefs indicate that the immunity argument was not made at all. ${ }^{77}$ Since it appears that immunity was not directly urged, it may be reasoned that the Supreme Court did not face, and therefore did not decide, the immunity question. ${ }^{78}$

\section{Practical Considerations in Racial Discrimination Cases}

The practicality of adopting the immunity doctrine in racial cases largely depends upon whether the doctrine can successfully serve the dual purposes of preserving the vitality and corrective force of the acts while protecting the morally blameless official. It is submitted that both purposes can be achieved provided the scope of the privilege is properly restricted to honest good-faith conduct within the legitimate sphere of official duty. The "scope" problem focuses upon the role assigned to "good faith." A superficial good-faith test resting upon surface appearances will, quite apparently, permit much intentional discrimination to escape the sanctions of the acts. For example, if the fact that an official acts pursuant to a statute is, by that fact alone, taken to be good-faith conduct, the immurity doctrine will place many instances of intentional misconduct beyond the reach of the damage provisions of the Civil Rights Acts.

The experience gained from enforcement of the criminal provisions ${ }^{79}$ of the Civil Rights Acts, however, suggests the feasibility of a workable good-faitl test capable of transcending outward appearances. The good-faith question is implicit in criminal Civil Rights Acts proceedings by reason of the statutory requirement

72 See Argument for Plaintiff in Error, Myers v. Anderson, 238 U.S. 368, 369-74 (1915).

73 Id. at 371 .

74 One other nonliability argument made by the defendant was based on the inseparability of the statute. If the "grandfather clause" was invalid, the rest of the statute was also void. Since the defendant registrars were appointed under the authority of the same statute, if the statute were void, the registrars were without authority to register anyone and cannot be held liable for failing to register the plaintiff. Id. at 370. The court's opinion meets only the constitutional and the foregoing argument, apparently disregarding the immunity issue.

75 Smith v. Allwright, 321 U.S. 649 (1944); Nixon v. Herndon, 273 U.S. 536, 537 (1927).

76 See, generally, Briefs for State of Texas and for State Democratic Executive Committee of Texas as Amici Curiae, Smith v. Allwright, 321 U.S. 649 (1944); Argument for State of Texas, Nixon v. Herndon, 273 U.S. 536, 537-39 (1927).

77 See Brief for Respondents, Lane v. Wilson, 307 U.S. 268 (1939). Respondent's principal arguments, aside from constitutionality and failure to exhaust state remedies, were (1) if the registration statute were void, plaintiff could vote without registration; hence, he was not injured by defendant's refusal to register him and (2) if the statute were void, defendant has no authority to register anyone; hence, he cannot be held hable for "failure to do that which lie had no authority to do." Id. at 30,36. See also Arguments for Respondents, Nixon v. Condon, 286 U.S. 73, 79-81 (1932).

78 There appears to be no Supreme Court decision since Tenney v. Brandhove in which damages were sought from subordinate officials for executing orders that discriminated on basis of race. However, lower courts have, since Tenney, permitted money recoveries against subordinates in such circumstances without discussion of immumity. See, e.g., McDonald v. Key, 224 F.2d 608 (10th Cir. 1955).

7918 U.S.C. §§ $241-43$ (1952). 
that the defendant "willfully" discriminate. ${ }^{80}$ In Screws v. United States, ${ }^{81}$ Justice Douglas, joined by Chief Justice Stone and Justices Black and Reed, ${ }^{82}$ facing the due process void-for-vagueness problem, overcame it by construing "willfully" as follows: 83

For the specific intent required by the Act is an intent to deprive a person of a right which has been inade specific either by the express terms of the Constitution or laws of the United States or by decisions interpreting them. Take the case of a local officer who persists in enforcing a type of ordinance which the court has held invalid as violative of the guarantees of free speech or freedom of worship. Or a local official who continues to select juries in a manner which flies in the teeth of decisions of the court. If those acts are done willfully, how can the officer possibly claim that he had no fair warning that his acts were prohibited by the statute?84

Although the purpose of the foregoing was to supply fair notice required by due process, the conceptual similarity between wilful wrongdoing and want of good faith would seem to permit a transplanting of the Screws scienter notion into the good-faith test for himited immunity. ${ }^{85}$ Thus the execution of a legislative, judicial, or other order which the subordinate knows, or reasonably should know, infringes upon federally-secured rights can be deemed imconsistent with the exercise of good faith. ${ }^{86}$

An additional means of limiting the scope of immunity lies in the requirement that the conduct complained of arise within the sphere of proper authority. There are indications that the bounds of a subordinate official's duties can be construed much more narrowly ${ }^{87}$ than was done with legislative duties in Tenney v. Brandhove. ${ }^{88}$

8018 U.S.C. $\$ 242$ (1952) provides in part: "Whoever, under color of any law, ... willfully subjects ... any inhabitant of any State, Territory or District to the deprivation of any rigbts, privileges or immumities secured or protected by the Constitution and laws of the United States... shall be fined not more than $\$ 1,000$, or imprisoned not more tban one year, or both." (Emphasis added.)

81325 U.S. 91 (1945).

82 There is no majority opmion in Screws $v$. United States, three justices joining with Justice Douglas in the "opinion of the court."

83 Screws v. United States, 325 U.S. 91, 104 (1945).

84 The Screwes test quoted im the text was approved by the majority of the Supreme Court in Williams v. Umited States, 341 U.S. 97 (1951).

85 Guinn v. United States, 238 U.S. 347 (1915), affirmed the crimmal conviction of lesser officials executing state constitutional provisions denying Negroes the right to register. Although the due process argument apparently was not argued before the Court, the jury instructions (quoted and seemingly approved by the Supreme Court) are illuminating. The jurors wero instructed that notwithstanding the existence of the discriminatory state constitutional mandate, if the registration officials "knew or believed that [the plaintiffs] ... were entitled to vote, and their purpose was to unfairly and fraudulently deny the right of suffrage to thein ... on account of their race and color, then their purpose was a corrupt one, and they cannot be shielded by their official positions." Id. at 356 .

$86 \mathrm{It}$ is interesting to note that California bas, by statute, achieved results very similar to the limited good-faith immunity rule where an official acts under an unconstitutional statute. CAL. Govr. CODE $\$ 1955$ provides: "If any officer, agent, or employee of the State, a district, county, political subdivision, or city acts in good faith and without malice under the apparent authority of any law of the State ... and the law subsequently is judicially declared ... unconstitutional as in conflict with the Constitution of the State or of the United States, he is not civilly hable in any action im which he would not have been liable if the law had not been declared unconstitutional ...." (Emphasis added.) See also Tracy v. County of Fresno, 125 Cal. App. 2d 52, 270 P.2d 57 (1954), for a case discussing the "good faith and without malice" requirement under California statutes.

87 See Lewis v. Brautigam, 227 F.2d 124, 128-29 (5th Cir. 1955) (reversing dismissal of damage action against prosecuting attorney on grounds that official immunity, if generally applicable, not available as defendant had exceeded scope of authority).

88 In Tenney v. Brandhove, 341 U.S. 367 (1951), Justice Frankfurter introduced a test by which to determine the scope of legislative authority. The test sets the bounds of such authority 
Also to be considered is the increasing practice of perpetrating racial discrimination by unconstitutionally applying otherwise valid statutes. ${ }^{89}$ An example is the discriminatory administration of literacy tests for voter registration. ${ }^{90}$ Adoption of the immunity doctrine would appear to lave little or no adverse effect on the outcome of these cases. The great practical problem in ineeting this subtler form of oppression is in properly proving intentional discrimination. However, any scheme of such discrimination, once established, inherently proves bad faith and the immunity privilege would not be available.

The final factor for consideration is that legal damages are not the only remedies available under the Civil Rights Acts. In addition to criminal sanctions the acts provide for equitable remedies. Section 1983 of the acts establishes "an action at law, suit in equity or other proper proceeding for redress." ing, there were thirty-one reported racial discrimination claims arising under sections 1983 and 1985(3) since Tenney $v$. Brandhove; im all but six of these cases equitable rather than legal remedies were sought. Three of the six cases looking to damages involved corporate (public carriers) rather than individual defendants. ${ }^{92}$ Two others concerned intentional instead of unknowing good-faith discrimination..$^{93}$ Only one involved an action for damages against an individual defendant who might have acted in good faith. ${ }^{94}$ Further, the more recent instances of Negro disfranchisement, unlike the older "wlite primary" cases, were corrected by commencing actions for equitable and not legal relief. ${ }^{95}$

It is possible that the seeming preference for equitable remedies in instances of racial discrimination is due to the prospective effect of declaratory judgments and injunctions and to the greater desirability im preventing future wrong rather than redressing past injury. Nevertheless, equitable remedies alone cannot be as effective as a combination of equitable and legal modes of relief. Reliance solely upon equity will require a far greater number of suits and additional expense. For example, if school board $A$ is enjoined from denying equal educational opportunities to certain racial groups, school board $B$ in another school district, operating under slightly different but equally discriminatory admission rules, may feel safe in continuing to discriminate until actually enjoined. However, if the threat of personal liability is also present, members of $B$ will be less prone to continue the

at the furthermost limits. To find a legislator had exceeded the "bounds of legislative power, it must be obvious that there was a usurpation of functions exclusively vested in the Judiciary or Executive." Id. at 378 .

89 See, e.g., Williams v. McCully, 128 F. Supp. 897 (W.D. La. 1955) (alleged discriminatory administration of literacy test); Sellers v. Wilson, 123 F. Supp. 917 (M.D. Ala. 1954) (discriminatory enforcement of registration statute).

90 See Williams v. McCully, 128 F. Supp. 897 (W.D. La. 1955).

91 See note 23 supra.

82 Spears v. Transcontinental Bus System, 226 F.2d 94 (9th Cir. 1955) (relief denied; defendant corporation did not have sufficient control over discriminating subsidiary); Flemming v. South Carolina Elec. and Gas Co., 224 F.2d 752 (4th Cir. 1955) (relief granted); Moore v. Atlantic Coast Line R.R., 98 F. Supp. 375 (E.D. Pa. 1951) (relief granted). In these cases color of law is normally found in the segregation statutes which commission the carrier personnel as police officers for the purpose of enforcing the statutes.

93 Williams v. McCully, 128 F. Supp. 897 (W.D. La. 1955) (discriminatory administration of literacy test) ; Sellers v. Wilson, 123 F. Supp. 917 (M.D. Ala. 1954) (discriminatory application of registration statute).

94 McDonald v. Key, 224 F.2d 608 (10th Cir. 1955) (officials enforcing statute requiring racial designation of nonwhite candidates on election ballot).

95 Terry v. Adams, 345 U.S. 461 (1953) ; Baskin v. Brown, 174 F.2d 391 (4th Cir. 1949); Rice v. EImore, 165 F.2d 387 (4th Cir. 1947), cert. denied, 333 U.S. 875 (1948). 
wrongful practices. It is to be noted also that by incorporating the Screws $v$. United States scienter test, the good-faith immunity doctrine can preclude a finding of good-faith conduct in the preceding example; hence, the threat of damages increases.

\section{Conclusion}

Although the immunity of judges, legislators and high executive officers in civil rights actions for damages seems well established, that of subordinates is still undergoing development. A few cases have accorded a limited good-faith immunity to subordinate officials in nonracial cases. The immunity approach to the problein posed by the well-meaning subordinate promises increased civil rights protection. The scope of the Civil Rights Acts may be broadened by reducing the tendency to resort to a strict construction of the acts to justify a deserving dismissal. Technical pleading and procedural requirements seemingly used to accomplish the same results may be relaxed. Thus, although the immunity doctrine may prevent recoveries in some actions covered by the acts, the doctrine will permit the extension and clarification of the coverage of the acts. The resulting certainty may induce the filmg of leretofore marginal claims which otherwise might not be pressed.

Courts granting immunity to subordinates liave restricted the doctrime to nonracial deprivations in probable deference to precedent and to fears of unduly sapping the vitahity of the acts. The racial-nonracial distmction can be justified on the grounds of both history and policy. However, restricting the immunity privilege on the basis of the defendant-official's conduct rather than the racial or nonracial character of the injury may be more desirable. That is, if immunity is accorded only upon a showing of honestly and reasonably entertained good-faith belief in the validity of official conduct, application of the privilege to both types of cases may not be as undesirable as supposed.

The registration and primary cases, starting with Myers $v$. Anderson, may be deceptive in appearing to impose strict liability in race cases. They were decided prior to Tenney v. Brandhove and there is evidence that the Supreme Court did not face, hence did not decide, the inmunity question. Further, the adoption of inmunity would be consistent with the historical purpose of the acts. The efficacy of the acts would be unimpaired as immunity would not be granted where goodfaith is lacking or where equitable rather than legal rehief is decreed. When racial discrimination results from well-meaning official conduct, it seems that equitable remedies will suffice; when intentional, the immumity doctrine still permits invoking both legal and equitable sanctions. It is submitted that extending immunity to all Civil Rights Acts cases, both racial and nonracial, may therefore be desirable, provided, however, that the good-faith requirement can be properly emphasized and effectuated by a meaningful, workable test.

Joe J. Yasaki 